\title{
Spatial Distribution and Species Composition of Seagrasses in Mannar Lagoon
}

\author{
R.R.M.K.P Ranatunga* , P.D.R.S. Pethiyagoda \\ Department of Zoology, University of Sri Jayewardenepura, Sri Lanka \\ *kamal.ranatunga@gmail.com
}

\begin{abstract}
Gulf of Mannar region has identified as "High Regional Priority Areas" by IUCN due to its high ecosystem and species diversity. Seagrass meadows play a significant role as primary producers sustaining a diversity of invertebrates, fish and other vertebrates such as dugong and sea turtles that inhabit or visit the area. Seagrasses also provide refuge for larval stages of many inhabitants as well as breeding colonies of several water birds.

Sampling was carried out in two field visits each lasting three days, between December 2013 and January 2014. Extensive survey was carried out in all the inundated habitats within the lagoon. Area lying within $500 \mathrm{~m}$ either side of the proposed over head transmission line (OHTL) within Vankalai Sanctuary were investigated. In the areas where the species diversity was very high, sampling was conducted in $100 \mathrm{~m}$ intervals whereas in other areas in $200 \mathrm{~m}$ intervals. Underwater visual surveys were carried out using diving and snorkeling. Underwater video and photo transects were acquired along a $50 \mathrm{~m}$ transect to obtain a permanent visual record of the biota and substrate. In addition, belt transect method was used to estimate the percent cover. Quadrates with an area of $1 \mathrm{~m}^{2}$ divided into 100 uniform grids was used along a $50 \mathrm{~m}$ transect with a minimum of three quadrate samples.
\end{abstract}

Seagrasses growing either homogenously or heterogeneously in mixed populations forming thick and dense meadows on muddy, sandy, clay soil of the lagoon and coastal areas in the shallow areas of the lagoon was a significant observation in this study. The Mannar lagoon is a favourable habitat for seagrasses due to shallowness and limited water movement.

Seagrass community recorded during the survey were; Tape Seagrass (Wattala) Enhalus acaroides, sickle seagrass Thalassia hemprichii, narrow leaf seagrass Halodule uninervis, noodle seagrass Syringodium isoetifolium, Cymodocea rotundata, Cymodocea serrulata, Oval-leaf Seagrass, Halophila ovalis, and Halophila decipiens.

Anthropogenic activities (i.e., harmful and unsustainable fishing methods such as drag nets) have led to the degradation of seagrass meadows with an indirect adverse effect on fish catch in the area. Seagrass beds are also affected by unplanned establishment of fish landing sites, and fishing boats.

Keywords: Mannar lagoon, Seagrass, Species composition, Spatial distribution 